\title{
PEMBANGUNAN KESADARAN HUKUM MASYARAKAT MELALUI DESA SADAR HUKUM DI KABUPATEN LEMBOK TIMUR
}

\author{
Basri Mulyani, Johan, Hairul Maksum \\ Fakultas Hukum Universitas Gunung Rinjani \\ e-mail: basrimulyani@ugr.ac.id \\ e-mail: johanmaligan1960@gmail.com \\ e-mail: hairulmaksum71@gmail.com
}

\section{Info Artikel}

Sejarah Artikel :

Diterima 07 Mei 2021

Disetujui 08 Mei 2021

Publikasi Mei 2021

\section{Keyword:}

Legal Counseling, Legal Awareness Village, East Lombok Regency.

\section{Albstract}

Legal counseling in the form of a "Legal Awareness Village" departs from the awareness of members of the community and local village government who on their own will strive to increase awareness and legal knowledge for themselves and village government officials. The purpose of developing a law-aware village is the realization of community legal awareness. Legal awareness is the output of the process of counseling and coaching activities that reach an ideal optimization level marked by a sense of respect for the law. The method used in this activity is in the form of a focused discussion that begins with counseling / lectures then continues with direct questions and answers. The extension participants were members of the community, especially women and local community leaders. By understanding the law, it is hoped that the community's legal awareness will increase to respect the law. The issue of marriage under the age of 19 was the most questionable discussion in the three locations of legal counseling, namely Padak Guar village, Gereneng and Masbagik New North, East Lombok district and other legal issues related to the conditions of each village.

\section{Ahstrak}

Penyuluhan hukum dalam bentuk "Desa Sadar Hukum" berangkat dari kesadaran anggota masyarakat dan pemerintahan desa setempat yang dengan kemauannya sendiri berusaha untuk meningkat kesadaran dan pengetahuan hukum bagi dirinya dan aparat pemerintahan desa. Tujuan dari pembinaan desa sadar hukum adalah terwujudnya kesadaran hukum masyarakat. Kesadaran hukum merupakan keluaran (output) dari proses kegiatan penyuluhan dan pembinaan yang mencapai tingkat optimalisasi ideal yang ditandai dengan timbulnya rasa untuk menghargai hukum. Metode yang digunakan dalam kegiatan ini yaitu berupa diskusi terarah yang diawali dengan penyuluhan/ceramah kemudian dilanjutkan dengan tanya jawab secara langsung. Peserta penyuluhan yaitu warga masyarakat terutama kaum perempuan dan tokoh-tokoh masyarakat setempat. Dengan dipahaminya hukum, kesadaran hukum masyarakat diharapkan meningkat menjadi menghargai hukum. Permasalahan perkawinan dibawah umur 19 tahun menjadi diskusi paling banyak dipertanyakan di tiga lokasi penyuluhan hukum yang dilakukan yakni desa Padak Guar, Gereneng dan Masbagik Utara Baru Kabupaten Lombok Timur dan permasalahan hukum lainnya terkait dengan kondisi masing-masing desa. 


\section{A. PENDAhuluan}

Indonesia adalah Negara Hukum sebagaimana tercantum dalam UndangUndang Dasar Negara Republik Indonesia Tahun 1945 (UUD NRI 1945) pada Pasal 1 ayat (3) yang bunyinya merupakan kehendak rakyat (volonte generale) tertinggi bangsa Indonesia, selain itu prinsip Indonesia sebagai negara hukum mengandung arti bahwa hukum merupakan pilar utama dalam menggerakkan sendi-sendi kehidupan bermasyarakat, berbangsa dan bernegara untuk mencapai cita-cita negara. Cita-cita bangsa Indonesia adalah membentuk masyarakat adil dan makmur berdasarkan Pancasila. ${ }^{1}$

Pasal 1 ayat (3) UUD NRI 1945 tersebut mengandung konsekuensi bahwa segala bentuk penyelenggaraan negara harus berdasarkan aturan/hukum yang berlaku, dan hukum harus selalu di junjung tinggi dalam kehidupan berbangsa, bernegara, dan bermasyarakat. Artinya, struktur hukum bukan hanya untuk pemerintah yang wajib melaksanakan hukum secara konsekuen, namun masyarakat juga harus taat pada hukum yang ada agar terwujud sinergitas antara aturan hukum sebagai nilai-nilai dasar hukum yakni substansi, penegakan hukum sebagai strukturnya, dan masyarakat sebagai pengemban budaya hukum guna tercapainya tujuan akan nilai-nilai dasar hukum tersebut.

Sedangkan tujuan negara Indonesia sendiri antara lain yakni melindungi segenap bangsa Indonesia dan seluruh tumpah darah Indonesia, memajukan kesejahteraan umum, mencerdaskan kehidupan bangsa, ikut melaksanakan ketertiban dunia, berdasarkan

1 Moh. Mahfud MD, Membangun Politik Hukum, Menegakan Konstitusi, (Jakarta: Raja Grafindo, 2011), hlm 17 kemerdekaan, perdamaian abadi, dan keadilan sosial. ${ }^{2}$

Sebagai upaya untuk mewujudkan sistem hukum nasional Kementerian Hukum dan Hak Asasi Manusia telah menetapkan yang diantaranya melalui penetapan/pembentukan desa/kelurahan sadar hukum merupakan langkah yang stretegis. Sejak tahun 1980-an telah dicanangkan program kelurahan/desa sadar hukum (DSH) oleh Departemen Kehakiman (sekarang Kementerian Hukum dan HAM). Program ini dimaksudkan untuk menumbuhkan kesadaran masyarakat kelurahan/desa terhadap hukum formal maupun adat dan norma sosial. Program ini dijalankan melalui sosialisasi produk hukum dan adat oleh Kantor Wilayah Kementerian Hukum dan HAM (Kanwil Kemenkumham) kepada warga Kelurahan/Desa. Perguruan tinggi sebagai salah satu pilar pengembangan ilmu pengetahuan turut serta melakukan kesadaran hukum pada masyarakat tersebut melalui tri darma perguruan tinggi yakni penelitian dan pengabdian kepada masyarakat.

Karena setiap masyarakat tidak menerima hukum secara alamiah, melainkan melalui suatu proses belajar yang disadari maupun yang tidak disadari. ${ }^{3}$ Dengan demikian, jelas bahwa masyarakat harus melalui proses belajar untuk dapat menerima dan memahami hukum. Proses belajar itu bermacam-macam, baik secara formal maupun informal. Salah satu proses belajar yang dapat dilakukan bagi masyarakat yaitu sosialisasi/penyuluhan hukum.

Pasal 2 Peraturan Menteri Hukum dan Hak Asasi Manusia Republik Indonesia Nomor: M.01-Pr.08.10 Tahun 2006 tentang Pola Penyuluhan Hukum menjelaskan:

"bahwa Penyuluhan Hukum
diselenggarakan dengan tujuan

\footnotetext{
2 Pembukaan Undang-Undang Dasar 1945, alinea ke 4

3 Kusumohamidjojo, B. Ketertiban yang Adil: Problematik Filsafat Hukum. (Jakarta: Grasindo, 1999) hlm. 168.
} 
mewujudkan kesadaran hukum masyarakat yang lebih baik sehingga setiap anggota masyarakat menyadari dan menghayati hak dan kewajibannya sebagai warga negara dan mewujudkan budaya hukum dalam sikap dan perilaku yang sadar, patuh, dan taat terhadap hukum serta menghormati hak asasi manusia".

Pasal tersebut menegaskan bahwa adanya penyuluhan hukum sebagai upaya untuk mewujudkan budaya hukum. Budaya hukum dapat terwujud apabila kesadaran hukum masyarakat sudah terbangun, sehingga penting kiranya membangun kesadaran hukum masyarakat.

Menurut Bernard Arief Sidharta menyatakan:

"bahwa kesadaran hukum adalah proses terbentuknya kaidah-kaidah hukum. Kemampuan membedakan benar-salah, baik-buruk, adil-tidak adil, manusiawitidak manusiawi tersebut menyebabkan timbulnya dalam kesadaran manusia keyakinan bahwa dalam situasi konkret tertentu orang seharusnya berperilaku dengan cara tertentu karena hal itu adalah adil. Kesadaran bahwa dalam situasi tertentu orang seyogyanya berperilaku atau tidak berperilaku dengan cara tertentu karena dituntut keadilan disebut kesadaran hukum pribadi. Melalui proses interaksi antar sesama manusia di dalam masyarakat, lama kelamaan terbentuklah kesamaan perasaan tentang apa yang dirasakan adil atau tidak adil. Tentang apa yang seyogiyanya dilakukan atau tidak dilakukan dalam situsi-situasi tertentu karena hal itu dirasakan adil dan perlu untuk mewujudkan ketertiban dalam masyarakat dan dengan itu terbentuklah kesadaran hukum umum atau kesadaran hukum rakyat".4

4 Sidharta, B. A. Ilmu hukum Indonesia, Upaya pengembangan IImu hukum sistematik
Munculnya kesadaran hukum didorong oleh sejauh mana kepatuhan kepada hukum didasari oleh indoctrination, habituation, utility dan group identification. Proses itu terjadi melalui internalisasi dalam diri manusia. Kadar internalisasi inilah yang selanjutnya memberikan motivasi yang kuat dalam diri manusia atas persoalan penegakan hukum. Soerjono Soekanto menyatakan, "bahwa terdapat indikator kesadaran hukum masing-masing merupakan suatu tahapan bagi tahapan berikutnya: pengetahuan hukum, pemahaman hukum, sikap hukum, dan pola perilaku hukum".

Akan tetapi pada kenyataannya, penyimpangan hukum di masyarakat masih marak terjadi, mulai dari pelanggaran terhadap aturan hukum, hingga kejahatan yang sifatnya merugikan dan mengancam ketenteraman masyarakat belum sepenuhnya dapat dicegah dan diatasi. Terciptanya sebuah aturan hukum ternyata belum cukup untuk mewujudkan ketertiban dan kesejahteraan dalam masyarakat, hal tersebut disebabkan oleh berbagai faktor, salah satunya adalah kurangnya kesadaran hukum masyarakat itu sendiri.

Krabbe menyatakan bahwa kesadaran hukum merupakan kesadaran atau nila - nilai yang terdapat di dalam diri manusia, tentang hukum yang ada atau tentang hukum yang diharapkan ada. ${ }^{6}$ Sedangkan Soerjono Soekanto bahwa kesadaran hukum itu merupakan persoalan nilai -nilai yang terdapat pada diri manusia tentang hukum yang ada atau tentang hukum yang diharapakan ada. sebenarnya yang di tekankan adalah nilai-nilai tentang fungsi hukum dan bukan suatu penilaian hukum

yang responsif terhadap perubahan masyarakat. (Yogyakarta: Genta Publishing, 2013). hlm. 8-9

${ }^{5}$ Saifullah. Refleksi sosiologi hukum. (Bandung:

Refika Aditama, 2010), hlm. 105-106

${ }^{6}$ Achmad Ali dan wiwie Heryani. Menjelajahi kajian empiris terhadap hukum.m(Jakarta: Kencana, 2012), hlm. 141 
terhadap kejadiankejadian yang konkrit dala masyarakat yang bersangkutan. ${ }^{7}$

Pendapat berbeda dikemukakan oleh Paul Scholten yang dimaksud dengan kesadaran hukum adalah kesadaran yang ada pada setiap manusia tentang apa hukum itu atau apa seharusya hukum itu suatu kategori tertentu dari hidup kejiwaan kita dari mana kita membedakan antara hukum (recht) dan tidak hukum (onrecht) antara yang seyogyanya dilakukan dan tidak seyogyanya dilakukan. ${ }^{8}$ Sedangkan Sudikno Mertokusumo menyatakan bahwa kesadaran hukum berarti kesadaran tentang apa yang seyogyannya kita lakukan atau perbuatan atau yang seyogyannya tidak kita lakukan atau perbuat terutama terhadap orang lain. Ini berarti kesadaran akan kewajiban kita masing masing terhadap orang lain, ${ }^{9}$ dengan demikian, dapat dikatakan bahwa kesadaran hukum merupakan suatu dasar bagi terwujudnya nilai dan tujuan hukum, karena apabila hukum yang ada di dalam masyarakat dilaksanakan dengan penuh kesadaran, maka nilai-nilai kepastian hukum, kemanfaatan, keadilan serta tujuan hukum untuk mencapai kemakmuran, kebahagiaan, dan ketertiban bagi masyarakat yang menjalankannya pun akan terwujud.

Soekanto dalam Rosana mengemukakan 4 indikator yang membentuk kesadaran hukum yang secara berurutan (tahap demi tahap) yaitu: ${ }^{10}$

1. Pengetahuan hukum; merupakan pengetahuan seseorang berkenaan dengan perilaku tertentu yang diatur oleh hukum tertulis, yakni tentang

7 Soerjono Soekanto, Kesadaran hukum dan kepatuhan hukum.(Jakarta: Raja Grafindo Persada, 2002), hlm. 215

8 Marwan Mas. Penghantar ilmu hukum. (Bogor: Penerbit Ghaila Indonesia, 2014) hlm. 88

9 Sudikno Mertokusumo, Menigkatkan Kesadaran Hukum Masyarakat,Edisi Pertama, (Yogyakarta: Liberti, 1981) hlm 13

${ }^{10}$ Rosana, E. (2014). Kepatuhan Hukum sebagai Wujud Kesadaran Hukum Masyarakat. Jurnal TAPIs, 10 (1), 1-25. HIm. 14 apa yang dilarang dan apa yang diperbolehkan.

2. Pemahaman hukum; sejumlah informasi yang dimiliki oleh seseorang mengenai isi dari aturan (tertulis), yakni mengenai isi, tujuan, dan manfaat dari peraturan tersebut.

3. Sikap hukum (legal attitude); merupakan suatu kecenderungan untuk menerima atau menolak hukum karena adanya penghargaan atau keinsyafan bahwa hukum tersebutbermanfaat bagi kehidupaan manusia. Dalam hal ini sudah ada elemen apresiasi terhadap aturan hukum.

4. Pola perilaku hukum; tentang berlaku atau tidaknya suatu aturan hukum dalam masyarakat. Jika berlaku suatu aturan hukum, sejauh mana berlakunya itu dan sejauh mana masyarakat mematuhinya.

Selanjutnya permasalahan rendahnya kesadaran hukum masyarakat dapat diatasi melalui kebijakan-kebijakan yang dibuat pemerintah. Kebijakan yang dimaksud adalah kebijakan yang mengatur ruang publik, yang disebut juga sebagai kebijakan publik. Penyuluhan hukum sebagai kebijakan pemerintah dalam mengatasi masalah rendahnya kesadaran hukum dapat dilaksanakan melalui beberapa program, salah satunya adalah program penyuluhan hukum yang direalisasikan melalui pembentukkan desa sadar hukum.

Pembentukan desa sadar hukum sebagai pengimplementasian dari Peraturan Kepala BPHN Nomor: PHN.HN.03.05-73 Tahun 2008 tentang Pembentukan dan Pembinaan Keluarga Sadar Hukum dan Desa/Kelurahan Sadar Hukum. Desa Sadar Hukum sendiri merupakan desa yang telah dibina atau karena swakarsa dan swadaya sendiri memenuhi kriteria desa sadar hukum, dan terhadap sebuah desa yang telah memenuhi kriteria desa sadar hukum maka pemerintah melalui Menteri Hukum dan Hak Asasi Manusia memberikan penghargaan 
Anubhawa Sasana Desa kepada Gubernur, Bupati/Walikota, Camat dan Kepala desa yang desanya ditetapkan sebagai desa sadar hukum.

Lampiran II Peraturan Kepala Badan Pembinaan Hukum Nasional Nomor PHN.HN.03.05.-73 Tahun 2008 tentang Pembentukan dan Pembinaan Keluarga Desa/Kelurahan Sadar Hukum memuat beberapa kriteria bagi pembentukan desa sadar hukum yaitu:

1. Pelunasan kewajiban membayar pajak bumi dan bangunan mencapai $90 \%$ (sembilan puluh persen), atau lebih:

2. Tidak terdapat perkawinan di bawah usia berdasarkan ketentuan dalam Undang-Undang-Undang Nomor 16 Tahun 2019 tentang Perubahan atas Undang Nomor 1 Tahun 1974 tentang Perkawinan:

3. Angka kriminalitas rendah: Rendahnya kasus Narkoba.

4. Tingginya kesadaran masyarakat terhadap kebersihan dan kelestarian lingkungan; dan

5. Kriteria lain yang ditetapkan daerah; Bale Mediasi Desa

Berdasar paparan dari Kantor Wilayah Kemenkum HAM Provinsi Nusa Tenggara Barat, di Kabupaten Lombok Timur untuk desa/kelurahan sadar hukum baru di Kelurahan Kelayu Lingkungan Jorong dilakukan kegiatan tersebut, berangkat dari pemikiran sebagaimana yang terurai diatas Fakultas Hukum Universitas Gunung Rinjani melaksanakan kegiatan pengabdian kepada masyarakat dengan membangun emberio desa sadar hukum di Kabupaten Lombok Timur, sebagai lokasi keberadaan dari Universitas Gunung Rinjani. Kabupaten Lombok Timur adalah salah kabupaten di Nusa Tenggara Barat yang berada di timur pulau Lombok yang memiliki penduduk terbesar sekitar 1,3 juta jiwa dengan jumlah kecamatan 21 dan desa sebanyak 239 desa dan 15 kelurahan.
Sehingga pelaksanaan pengabdian ini terlaksana karena melihat beberapa permasalahan yang terjadi dalam masyarakat yang berkaitan dengan kesadaran hukum masyarakat dan apparat pemerintahan desa khususnya di 3 (tiga) Desa diwilayah Kabupaten Lombok Timur yang diklasifikasikan menjadi wilayah Lombok Timur bagian timur adalah Desa Padak Guar Kecamatan Sembelia, bagian Selatan adalah Desa Gereneng dan bagian tengah dengan Desa Masbagaik Utara Baru. Adapun permasalahannya adalah sebagai berikut: Bagaimana kesadaran hukum kaum perempuan utamanya dan masyarakat umumnya terhadap Undang-Undang Perkawinan tentang batas minimal umur menikah, hukum masyarakat untuk melakukan pendaftaran tanah dan pembayaran PBB, kesadaran hukum atas tindak pidana Kamtibmas, KDRT, Narkoba, sengketa waris dan Korupsi Dana Desa?

\section{B. METODE}

Metode yang digunakan dalam kegiatan ini yaitu berupa diskusi terarah yang diawali dengan penyuluhan/ceramah kemudian dilanjutkan dengan tanya jawab secara langsung. Peserta penyuluhan yaitu warga masyarakat terutama kaum perempuan dan tokoh-tokoh masyarakat setempat. Melalui penyuluhan dan ceramah dapat disampaikan materi-materi yang penting untuk diketahui dan dipahami oleh masyarakat, sedangkan melalui tanya jawab dapat melengkapi materi yang belum jelas serta untuk memberi masukan atas permasalahan yang dihadapi oleh warga masyarakat dalam menyelesaikan sengketa dimasyarakat dan pemerintahan dalam kehidupan sehari-hari. Penyuluhan hukum ini diutamakan bagi kaum perempuan karena mereka memiliki potensi dan kesempatan untuk menyampaikan kembali materi penyuluhan kepada anggota masyarakat dilingkungan sekitarnya terutama dalam lingkunga keluarga intinya. 
Berdasarkan Peraturan Menteri Hukum dan HAM RI No: M.01-Pr.08.10 Tahun 2006 Tentang Pola Penyuluhan Hukum disebutkan tentang metode-metode penyuluhan hukum bagi warga masyarakat. Metode-metode tersebut terdiri dari penyuluhan hukum langsung dan penyuluhan hukum tidak langsung. Penyuluhan hukum langsung dilakukan dengan cara bertatap muka secara langsung antara penyuluh dan yang disuluh, sementara penyuluhan hukum tidak langsung dilakukan melalui media elektronik dan media cetak. Mengacu kepada peraturan tersebut, pengabdian masyarakat ini dilakukan dengan cara penyuluhan hukum langsung.

\section{PEMBAHASAN}

Desa Sadar Hukum dibentuk oleh anggota masyarakat dan pemerintahan desa setempat yang dengan kemauannya sendiri berusaha untuk meningkat kesadaran dan pengetahuan hukum bagi dirinya dan apparat pemerintahan desa. Tujuan dari pembinaan Desa sadar hukum adalah terwujudnya kesadaran hukum masyarakat. Kesadaran hukum merupakan keluaran (output) dari proses kegiatan penyuluhan dan pembinaan yang mencapai tingkat optimalisasi ideal yang ditandai dengan timbulnya rasa untuk menghargai hukum.

Dengan dipahaminya hukum, kesadaran hukum masyarakat diharapkan meningkat menjadi menghargai hukum. Tahap memahami hukum menjadi menghargai hukum dapat terjadi apabila dalam proses memahami tersebut warga masyarakat menghayati tentang adanya manfaat hukum bagi kehidupan bersama di dalam masyarakat bersangkutan, dan hal ini bila warga masyarakat tersebut mengetahui tujuan dan tugas hukum yang sesungguhnya diperlukan. Berangkat dari tujuan tersebut berikut hasil penyuluhan hokum yang telah dilakukan di 3 (tiga) desa wilayah Kabupaten Lombok Timur sebagai berikut:

\section{Desa Sadar Hukum Desa Padak Guar Kecamatan Sembelia}

Desa Padak Guar yang berada di kecamatan Sembelia adalah salah satu desa yang dapat digolongan sebagai daerah industri ketenagalistrikan dengan adanya 2 (dua) Pembangkit Listrik Tenaga Uap (PLTU) yakni PLTU milik PT. Lombok Energy Dynamics dan PLTU milik PT. PLN (Persero) yang berada tepat di depan kantor desa. Selain usaha ketenagalistrikan juga adanya usaha tambak udang. Selain industri wilayah Desa Padak Guar yang luasnya $1.800 \mathrm{Ha}$ (18 $\mathrm{Km} 2$ ) juga memiliki kawasan pariwisata yang sudah cukup terkenal dengan gili (pulau) yakni gili kondo dan gili bidara serta gili layar disekitar (3) tiga gili tersebut terdapat juga salah satu gili yang masuk desa Labuhan Pandan yakni gili petagan yang merupakan Kawasan konservasi hutan bakau.

Jumlah penduduk Desa Padak Guar pada tahun 2021 menurut data Dinas Kependudukan dan Catatan Sipil adalah 3124 jiwa dengan jumlah laki-laki sebanyak 1577 jiwa dan perempuan 1565 jiwa. ${ }^{11}$ Batas wilayah sebelah utara dengan desa Labuhan Pandan, sebelah selatan dengan Desa Gunung Malang, Kawasan perhutanan yang masuk bagian dari Gunung Rinjani disebelah barat dan sebelah timur berbatasan dengan selat alas, sehingga di desa Padak Guar terdapat Pos TNI AL (Danposal) Selat Alas.

Desa Padak Guar adalah miniatur Bangsa Indonesia, karena warganya pemeluk Agama Islam, Agama Kristen dan Agama Hindu, selama ini warga Desa Padak Guar selalu menjaga toleransi beragama. Tingkat Pendidikan masyarakat desa Padak Guar rata-rata adalah Sekolah Dasar (SD) sedangkan yang menempuh Pendidikan tinggi tidak terlalu banyak, karena sekolah di Padak Guar hanya ada 2 SD dan 3 PAUD, dengan pekerjaan masyarakat sebagian besar adalah sebagai petani dan buruh tani

\footnotetext{
${ }^{11} \mathrm{https}$ ://dukcapil.lomboktimurkab.go.id/statis-90jumlah-penduduk-desa-di-kecamatan-sambelia.html
} 
Kegiatan penyuluhan hokum desa sadar hokum di Desa Padak Guar atas kerjasama Pemerintah Desa Padak Guar dengan Fakultas Hukum Universitas Gunung Rinjani dilaksanakan pada tanggal 19 Oktober 2020 dengan penyuluh dari Fakultas Hukum Universitas Gunung Rinjani yakni Basri Mulyani, SH.,MH (penyuluh hukum administrasi negara), Johan, $\mathrm{SH} ., \mathrm{MH}$ dan Hairul Maksum, SH., MH (penyuluh hukum perdata), Hj. Harmiati, S.Ag., MH (penyuluh hukum perkawinan) dan Lalu Muh. Faisal, $\mathrm{SH} ., \mathrm{MH}$ (penyuluh hukum agraria). Kegiatan penyuluhan yang dihadiri sekitar 30 orang masyarakat dari laki-laki maupun perempuan dan aparatur desa Padak Guar. Penyuluhan hukum dengan prokes Covid 19 dimulai dari Pemaparan dari $\mathrm{Hj}$. Harmiati, S.Ag., $\mathrm{MH}$ yang menyampaikan dampak pernikahan dini dan sosialisasi Undang-Undang Nomor 16 Tahun 2019 tentang Perubahan atas Undang Nomor 1 Tahun 1974 tentang Perkawinan yang menguraikan adanya perubahan batas umur dapat melangsung perkawinan adalah 19 tahun, dalam pemaparan tersebut juga disampaikan jika terjadi perkawinan dibawah umur 19 tahun masyarakat disarankan untuk mengajukan permohonan ke Pengadilan Agama untuk mendapatkan dispensasi perkawinan.

Penyuluh kedua Lalu Muh. Faisal, SH., $\mathrm{MH}$ memaparkan materinya terkaitnya pentingnya pendaftaran hak atas tanah dengan mengajukan pensertifikatan tanah menurut Peraturan Pemerintah Nomor 24 Tahun 1997 tentang Pendaftaran Tanah, karena tidak cukup hanya dengan memiliki SPPT (pajak PBB) atas tanah dapat dinyatakan tanah tersebut sebagai hak milik. Kepemilikan tanah dengan bukti sertifikat menjadi penting sebagai bukti hak, walau sertifikat bukan bukti yang materiil akan tetapi mengurangi sengketa kepemlikan di desa tidak sering terjadi.

Pemaparan terakhir dilakukan oleh Johan, SH., MH dan Hairul Maksum, SH., MH terkait dengan daerah industry di Desa Padak
Guar yang dapat dikolaborasi oleh Pemerintah Desa dengan dana CSR perusahaan untuk pembangunan masyarakat desa. Karena setelah keluarnya UU Nomor 40 Tahun 2007 tentang Perseroan Terbatas, kegiatan CSR atau tanggungjawab social perusahaan menjadi kewajiban UndangUndang. Perlu diingat bahwa pembangunan suatu negara bukan hanya tanggung jawab pemerintah dan industri saja, tetapi setiap insan manusia berperan untuk mewujudkan kesejahteraan sosial dan pengelolaan kualitas hidup masyarakat. Industri dan korporasi berperan untuk mendorong pertumbuhan ekonomi yang sehat dengan mempertimbangkan pula faktor lingkungan hidup.

Menurut Pasal 1 angka 3 UUPT, Tanggung Jawab Sosial dan Lingkungan adalah komitmen perseroan untuk berperan serta dalam pembangunan ekonomi berkelanjutan guna meningkatkan kualitas kehidupan dan lingkungan yang bermanfaat, baik bagi perseroan sendiri, komunitas setempat, maupun masyarakat pada umumnya. Mengenai TJSL, diatur dalam Pasal 74 UUPT dan penjelasannya. Pengaturan ini berlaku untuk perseroan.

(1) Perseroan yang menjalankan kegiatan usahanya di bidang dan/ atau berkaitan dengan sumber daya alam wajib melaksanakan Tanggung Jawab Sosial dan Lingkungan.

(2) Tanggung Jawab Sosial dan Lingkungan merupakan kewajiban Perseroan yang dianggarkan dan diperhitungkan sebagai biaya Perseroan yang pelaksanaannya dilakukan dengan memperhatikan kepatutan dan kewajaran.

(3) Perseroan yang tidak melaksanakan kewajiban dikenai sanksi sesuai dengan ketentuan peraturan perundang-undangan.

(4) Ketentuan lebih lanjut mengenai Tanggung Jawab Sosial dan 


\section{Lingkungan diatur dengan \\ Peraturan Pemerintah.}

Terakhir dari penyuluh Basri Mulyani, $\mathrm{SH} ., \mathrm{MH}$ menyampaikan pentingnya peran serta masyarakat dalam membangun kesadaran hukum dilingkungan desa maupun dusun untuk pembangunan desa dan masyarakat. Pemerintah desa wajib menjadi katalisator dan mediator dalam pembentukan kesadaran hukum masyarakat. Setiap permasalahan hukum yang ada di desa di upaya diselesaikan terlebih dahulu di desa dengan cara-cara mediasi karena pilihan ke pengadilan adalah upaya terakhir (ultimum remidium). Sehingga penyuluhan hukum yang sangat dinamis tersebut menghasilkan rekomendasi penting adanya dinamika diskusi khususnya terkait permasalahan Gerhan di Desa Padak Guar yang banyak menyebabkan masyarakat desa berurusan dengan hukum, demikian yang disampaikan Lalu. Rohyadi dari Ketua Karang Taruna Desa Padak Guar, masyarakat Desa Padak Guar berharap perlu adanya pendampingan hukum dari Fakultas Hukum Universitas Gunung Rinjani untuk menumbuh kembangkan kesadaran hukum masyarakat.

\section{Desa Sadar Hukum Desa Gereneng Kecamatan Sakra Timur}

Sekitar tiga tahun lalu masyarakat Desa Gereneng dikejutkan dengan dengan perusakan delapan rumah orang Aahmadiyah dan sekitar 23 orang penganut aliran tersebut harus dievakuasi oleh Polres Lombok Timur. Gambaran tersebut menjadi sejarah konflik atas penolakan masyarakat Gereneng terhadap aliran Ahmadiyah di Desa tersebut. Desa Gereneng Kecamatan Sakra Timur Kabuparen Lombok Timur merupakan bagian dari wilayah kecamatan Sakra Timur yang tergolong desa induk, karena desa Gereneng telah

melakukan pemekaran wilayah pada tahun 2010. Desa gereneng merupakan desa dengan mata pencaharian masyarakat dari hasil pertanian, Desa gereneng sering terjadi kemarau yang berkepanjangan sehingga sering terjadi gagal panen. Kenakalan remaja merupakan permasalahan yang mendasar, sering terjadi perkelahian antara desa maupun antara masyarakat dalam desa, sehingga perlu penengan yang serius, karena hal tersebut merupakan kendala dalam Pemerintahan Desa, sosial kemasyarakatan dan pembangunan.

Desa Gereneng Kecamatan Sakra Timur Kabupaten Lombok Timur merupakan salah satu desa yang terletak dipertengah desa antara desa lenting dan desa lepak dengan luas wilayah $\pm 518,700 \mathrm{ha} / \mathrm{m}^{2}$, dengan pengunaan lahan pertanian yang paling luas, Jumlah Penduduknya 5953 jiwa dengan jumlah kepala keluarga (KK) 2124 KK, dimana jumlah penduduk laki-laki sebanyak 2.124 jiwa dan Perempuan sebanyak 3047 jiwa. Keadaan kehidupan sosial masyarakat Desa Gereneng yang ditandai oleh tingkat kesejahteraan masyarakat yang rata-rata adalah masyarakat sejahtera. Tingkat Pendidikan rata-rata masyarakat Gereneng adalah tamat Sekolah Dasar, untuk sekolah di desa Gereneng telah ada SD, SMP maupun SMA. Sebagian besar masyarakatnya menggantungkan hidup dari bertani dan menjadi buruh. Agama mayoritas masyarakat Gereneng adalah Islam sebanyak 5953 jiwa.

Kegiatan penyuluhan hUkum desa sadar hukum di Desa Gereneng dari Fakultas Hukum Universitas Gunung Rinjani dipadukan dengan Fokus Group Discussion tentang kemitraan Polri dan masyarakat dalam menjaga situasi Kamtibmas yang kondusif dilaksanakan pada tanggal 4 Maret 2021. Dalam kegiatan bersama-sama dengan kepolisian tersebut berangkat dari banyak kenakalan remaja, pelaku tindak pidana dengan kekerasan dan yang terakhir adalah masalah Ahmadiyah di Desa Gereneng, Kegiatan ini diikuti oleh sekitar 40 orang baik dari laki-laki maupun perempuan yang terdiri dari tokoh masyarakat, tokoh pemuda, tokoh agama, staf pemerintahan desa, kader posyandu dan lain-lain.

Penyampaian materi diawali dari Satuan Bimbingan dan Pembinaan Masyarakat (Binmas) Polres Lombok Timur menyampaikan kondisi desa Gereneng dalam bulan ini sangat kondisif, sehingga diharapakan pada acara kepolisian dalam menjaga kamtibmas yang dipadu dengan penyuluhan hukum desa sadar hukum dari Universitas Gunung Rinjani sama-sama 
beriringan sesuai dengan tugas masingmasing yang tujuannya adalah sama-sama terciptanya kedamaian. Dari Universitas Gunung Rinjani yang diwakili oleh Lalu Muh. Faisal, $\mathrm{SH}$., $\mathrm{MH}$ tentang pendaftaran tanah menjadi penting untuk meminimalisir konflik pertanahan dan bukti pembayaran pajak PBB yang penting ketika pensertifikatan tanah sudah dilakukan.

Sedang Johan, $\mathrm{SH} ., \mathrm{MH}$ menyampaikan bahwa perguruan tinggi memiliki program pengabdian kepada masyarakat selain pengajaran dan penelitian. Salah satu program pegabdian masyarakat yang dilakukan adalah penyuluhan hukum desa sadar hukum. Seperti yang telah diuraikan persoalan pensertipikatan tanah menjadi penting apalagi dijaman digitalisasi sekarang ini. Semua orang yang memiliki tanah atau objek tanah yang telah disertipikatkan dengan membuka peta tanah pada website kantor pertanahan sudah akan terlihat luas dan siapa pemiliknya. Sehingga hanya sertipikat yang diakui oleh negara adalah bukti hak bukan SPPT (pajak tanah).

Pertanyaan peserta diskusi pada peran kepolisian dalam membangun hubungan dengan kepala daerah dalam menciptakan kamtibmas sedanhkan untuk akademisi bagaimana yang disampaikan soal aturan hukum apakah penerapannya akan sama dengan kondisi masyarakat hari ini sebagai contoh ada kasus di pengadilan sertipikat dikalahkan oleh sebuah pipil dan letter $C_{\text {, }}$ bagaimana permasalahan ini.

Menurutnya penyuluh dalam digitalisasi sertifikat tanah perlu dibuat double security bahkan triple security. Selain ada barcode dan password bisa ditambahkan tekhnologi biometrik seperti fitur sidik jari, retina, wajah bahkan identifikasi irama suara guna memberikan tingkat keamanan dan kepercayaan dalam mengotentifikasi dan validasi keabsahan seritifikat itu. Dalam program digitalisasi pertanahan ini, sertifikat tanah elektronik ini juga bisa dibuat mekanisme dan sistem pengamanan berlapis untuk verifikasi dan validasi sertifikat. Kalau sudah efektif berjalan program ini, maka dengan sendirinya kepemilikan tanah dengan bukti-bukti lama menjadi sesuatu yang lemah dalam pembuktian di pengadilan, berkaitan dengan sejarah tanah dalam artian kepemilikan tanah.
Sedangkan dari kepolisian menanggapi bahwa tugas utama kepolisian adalah keamanan dan ketertiban masyarakat, secara lebih sederhananya kalau masyarakat taat hukum tidak akan mungkin dihukum. Pola hubungan yang dilakukan antara kepolisian dengan pemerintah sederhananya adalah lomba kampung sehat terhadap penangganan Covid kita saling membahu dalam membantu pelaksanaan program pendemi ini menjaga agar tidak terjadi dampak yang meluas.

Namun, yang dimaksud kan adalah pembenahan dalam rangka memperkuat institusi (institutional capacity building) dalam rangka menghadirkan suatu lembaga penegakan hukum yang sungguh-sungguh mengabdi kepada kebenaran dan keadilan hukum tanpa dipengaruhi intervensi dalam bentuk apa pun dari luar, termasuk motifmotif uang dan politik.

\section{Desa Sadar Hukum Desa Masbagik Utara Baru Kecamatan Masbagik}

Desa Masbagik Utara Baru merupakan bagian dari wilayah Desa Masbagik Utara Sebelum dicanangkannya kebijakan pemekaran Desa oleh Pemerintah kabupaten Lombok Timur pada tahun 2009. Dengan jumlah penduduk sebanyak 6209 jiwa dan kepala keluarga sebanyak 1796 KK yang terdiri dari 3134 jiwa laki-laki dan 3075 jiwa perempuan. Tingkat Pendidikan di desa Masbagik Utara Baru rata-rata bersekolah dari Tamat SD sampai Doktor. Sebagian besar masyarakatnya menggantungkan hidup sebagai petani/pekebun, buruh harian lepas, pedagang dan wiraswasta. Sebanyak 6209 orang Masbagik Utara Baru beragama Islam atau $100 \%$.

Kegiatan penyuluhan hukum di Desa Masbagik Utara Baru dilaksanakan pada 10 Maret 2021, bertempat di aula desa Masbagik Utara Baru yang dihadiri dari lintas sector seKecamatan Masbagik terutama kelompok perempuan dari bidan dan kader posyandu. Camat Masbagik Drs. H. Muhiddin dihadapan 53 orang yang menghadiri penyuluhan tersebut menyampaikan sambutan sangat mengapresiasi kegiatan penyuluhan hukum ini ada 2 hal pokok terkait dengan perubahan UU Perkawinan yang menimal 19 tahun perlu diberikan pemahaman kepada kepala wilayah selaku 
lokomotif ditingkat bawah yang akan melaksanakannya. Kedua, Desa Masbagik Utara Baru sebagai pilot projek Bale Mediasi Desa, terakhir hukum waris ini yang perlu ditekankan karena permasalahan dibawah banyak sekali terkait dengan permasalahan waris dan disanalah perang fungsi bale mediasi desa agar permasalahan ini tidak sampai ke pengadilan. Pertanyaan dari peserta penyuluhan hukum sebagai berikut:

Pertama, UU No. 1 Tahun 1974, anak yang dapat menikah ketika sudah berumur 16 Tahun, akan tetapi sekarang 19 tahun, apa dasar penerapan sanksi tersebut, demikian dari Ketua Forum Kepala Wilayah dan sangat bersyukur dengan adanya penyuluhan ini. Kedua, pertanyaan dari Ketua Kader PKK menyampaikan ada kasus anak perempuan kabur dari rumah sampai tiga kali, dua kali dapat dipulangkan tetapi yang ketiga tidak dapat dilakukan dan anak perempuan itu ingin menikah tetapi umurnya dibaah 19 tahun. Apakah pihak-pihak yang menikahkan itu dapat dipenjara dan di denda. Kader PKK desa Masbagik Utara Baru akan menyelenggarakan Penyuluhan Hukum tentang pernikahan dini besar harapan dari PKK dapat bekerjasama dan menajdi pemateri selanjutnya. Ketiga, Kepala Dusun Paok Kambut, Sahril menyatakan, pernah terjadi kasus pernikahan anak dibawah umur ketika kami akan menikahkan maupun tidak menikahkan menjadi serbar salah bagaimana cara menyikapinya. Kedua permasalahan perceraian, dimana banyak perempuan yang menggugat suaminya dipengadilan, apa alasan paling kuat untuk mengajukan perceraian di pengadilan.

M. Zainuddin, $\mathrm{SH} ., \mathrm{MH}$ selaku penyuluh hukum pidana menyampaikan perubahan umur batas minimal menikah bagi anak perempuan dan laki-laki yang berlaku sama yakni 19 tahun di dasarkan pada hasil putusan judisial review di Mahkamah konstitusi yang kemudian melahirkan UU Nomor 16 Tahun 2019 tentang perubahan UU Nomor 1 Tahun 1974 tentang Perkawinan, dalan pasal 7 menyatakan:

(1) Perkawinan hanya diizinkan apabila pria dan wanita sudah mencapai umur 19 (sembilan belas) tahun.

(2) Dalam hal terjadi penyimpangan terhadap ketentuan umur sebagaimana dimaksud pada ayat
(1), orang tua pihak pria dan/atau orang tua pihak wanita dapat meminta dispensasi kepada Pengadilan dengan alasan sangat mendesak disertai bukti-bukti pendukung yang cukup.

(3) Pemberian dispensasi oleh Pengadilan sebagaimana dimaksud pada ayat (2) wajib mendengarkan pendapat kedua belah calon mempelai yang akan melangsungkan perkawinan.

(4) Ketentuan-ketentuan mengenai keadaan seorang atau kedua orang tua calon mempelai sebagaimana dimaksud dalam Pasal 6 ayat (3) dan ayat (41 berlaku juga ketentuan mengenai permintaan dispensasi sebagaimana dimaksud pada ayat (2) dengan tidak mengurangi ketentuan sebagaimana dimaksud dalam Pasal 6 ayat (6).

Sedangkan pidana yang dapat diterapkan kepada semua pelaku dapat dijerat dengan tindak pidana biasa, baik yang menikahkan maupun yang melakukan pernikahan.

Hal senada juga disampaikan oleh Basri Mulyani, SH., MH selaku penyuluhh yang menyatakan, Pasal 7 ayat (1) UndangUndang Nomor 1 Tahun 1974 menyatakan bahwa perkawinan hanya diizinkan apabila pihak pria mencapai umur 19 (sembilan belas) tahun dan pihak wanita sudah mencapai usia 16 (enam belas) tahun, ketentuan tersebut memungkinkan terjadinya perkawinan dalam usia anak pada anak wanita karena dalam Pasal 1 angka 1 Undang-Undang tentang Perubahan Atas Undang-Undang Nomor 23 Tahun 2002 tentang Pelindungan Anak didefinisikan bahwa anak adalah seseorang yang belum berusia 18 (delapan belas) tahun, termasuk anak yang masih dalam kandungan.

Mahkamah Konstitusi Republik Indonesia telah mengeluarkan Putusan Mahkamah Konstitusi Nomor 22/PUU-XV/2017 yang salah satu pertimbangan Mahkamah Konstitusi dalam putusan tersebut yaitu "Namun tatkala pembedaan perlakuan antara pria dan wanita itu berdampak pada atau menghalangi pemenuhan hak-hak dasar atau 
hak-hak konstitusional warga negara, baik yang termasuk ke dalam kelompok hak-hak sipil dan politik maupun hak-hak ekonomi, pendidikan, sosial, dan kebudayaan, yang seharusnya tidak boleh dibedakan sematamata berdasarkan alasan jenis kelamin, maka pembedaan demikian jelas merupakan diskriminasi." Dalam pertimbangan yang sama juga disebutkan Pengaturan batas usia minimal perkawinan yang berbeda antara pria dan wanita tidak saja menimbulkan diskriminasi dalam konteks pelaksanaan hak untuk membentuk keluarga sebagaimana dijamin dalam Pasal 28B ayat (1) UUD 1945, melainkan juga telah menimbulkan diskriminasi terhadap pelindungan dan pemenuhan hak anak sebagaimana dijamin dalam Pasal 28B ayat (2) UUD 1945.

Penjelasan UU Nomor 16 Tahun 2019 juga mempertegas putusan Mahkamah Konstitusi yang harus dilaksanakan dengan perubahan Undang-Undang dalam jangka waktu tiga bulan, demikian penjelasan UU tersebut: "Dalam hal ini, ketika usia minimal perkawinan bagi wanita lebih rendah dibandingkan pria, maka secara hukum wanita dapat lebih cepat untuk membentuk keluarga. Oleh karena hal tersebut, dalam amar putusannya Mahkamah Konstitusi memerintahkan kepada pembentuk undangundang untuk dalam jangka waktu paling lama 3 (tiga) tahun melakukan perubahan terhadap Undang-Undang Nomor 1 Tahun 1974 tentang Perkawinan". 12

Perubahan norma dalam Undang-Undang Nomor 1 Tahun 1974 tentang Perkawinan ini menjangkau batas usia untuk melakukan perkawinan, perbaikan norma menjangkau dengan menaikkan batas minimal umur perkawinan bagi wanita. Dalam hal ini batas minimal umur perkawinan bagi wanita dipersamakan dengan batas minimal umur perkawinan bagi pria, yaitu 19 (sembilan belas) tahun. Batas usia dimaksud dinilai telah matang jiwa raganya untuk dapat melangsungkan perkawinan agar dapat mewujudkan tujuan perkawinan secara baik tanpa berakhir pada perceraian dan mendapat keturunan yang sehat dan

12 Penjelasan Undnag-Undang Nomor 16 Tahun 2019 tentang Perubahan atas Undang-Undang Nomor 1 Tahun 1974 tentang Perkawinan (Lembaran Negara RI Tahun 2019 Nomor 186, Tambahan Lembaran Negara RI Nomor 6401) berkualitas. Diharapkan juga kenaikan batas umur yang lebih tinggi dari 16 (enam belas) tahun bagi wanita untuk kawin akan mengakibatkan laju kelahiran yang lebih rendah dan menurunkan resiko kematian ibu dan anak. Selain itu juga dapat terpenuhinya hak-hak anak sehingga mengoptimalkan tumbuh kembang anak termasuk pendampingan orang tua serta memberikan akses anak terhadap pendidikan setinggi mungkin. ${ }^{13}$

\section{PENUTUP}

Berdasarkan uraian di atas dapatlah ditarik suatu kesimpulan sementara, bahwa masalah pokok pembangunan kesadaran hukum masyarakat sebenarnya terletak pada faktot-faktor yang mungkin mempengaruhinya. Faktor-faktor tersebut mempunyai arti yang netral, sehingga dampak positif atau negatifnya terletak pada isi faktor-faktor tersebut. Faktor-faktor tersebut, adalah sebagai berikut:

1) Faktor hukumnya sendiri, yang di dalam tulisan ini akan dibatasi pada Undang-Undang saja.

2) Faktor penegak hukum, yakni pihakpihak yang membentuk maupun menerapkan hukum.

3) Faktor sarana atau fasilitas yang mendukung penegakan hukum.

4) Faktor masyarakat, yakni lingkungan di mana hukum tersebut berlaku atau diterapkan.

5) Faktor kebudayaan, yakni sebagai basil karya, cipta, dan rasa yang didasarkan pada karsa manusia di dalam pergaulan hidup.

Kelima faktor tersebut saling berkaitan dengan eratnya, oleh karena merupakan esensi dari kesadaran hukum, juga merupakan tolok ukur daripada efektivitas kesadaran hukum dalam menciptakan desa sadar hukum. Sehingga upaya-upaya yang dapat dilakukan untuk meningkatkan kesadaran hukum masyarakat dan pemerintah sehingga penegakan prinsip-

\footnotetext{
13 Ibid
} 
prinsip negara hukum dapat berjalan dengan baik yaitu:

1) Melakukan penyuluhan hukum kepada masyarakat secara menyeluruh dan berkesinambungan.

2) Melakukan pembaharuan hukum.

3) Proses hukum tidak boleh didasarkan pada motifasi politik.

4) Menjunjung tinggi hak asasi manusia serta tidak diskriminatif.

5) Melakukan pembenahan dalam rangka memperkuat institusi pemerintahan yang menghadirkan lembaga-lembaga penegak hukum yang sungguh-sungguh mengabdi kepada kebenaran, keadilan dan kepastian hukum.

\section{DAFTAR PUSTAKA}

Achmad Ali dan wiwie Heryani. Menjelajahi kajian empiris terhadap hukum.m(Jakarta: Kencana, 2012).

Kusumohamidjojo, B. Ketertiban yang Adil: Problematik Filsafat Hukum. (Jakarta: Grasindo, 1999).

Marwan Mas. Penghantar ilmu hukum. (Bogor: Penerbit Ghaila Indonesia, 2014).

Sudikno Mertokusumo, Menigkatkan Kesadaran Hukum Masyarakat, Edisi Pertama, (Yogyakarta: Liberti, 1981).

Moh. Mahfud MD, Membangun Politik Hukum, Menegakan Konstitusi, (Jakarta: Raja Grafindo, 2011).

Rosana, E. (2014). Kepatuhan Hukum sebagai Wujud Kesadaran Hukum Masyarakat. Jurnal TAPIs, 10 (1), 1-25.

Saifullah. Refleksi sosiologi hukum. (Bandung: Refika Aditama, 2010).

Sidharta, B. A. Ilmu hukum Indonesia, Upaya pengembangan IImu hukum sistematik yang responsif terhadap perubahan masyarakat. (Yogyakarta: Genta Publishing, 2013).
Soerjono Soekanto, Kesadaran hukum dan kepatuhan hukum.(Jakarta: Raja Grafindo Persada, 2002).

https://dukcapil.lomboktimurkab.go.id/statis90-jumlah-penduduk-desa-dikecamatan-sambelia.html 